\title{
Malignant Transformation of Neurofibromatosis in A Developing Community: Case Report
}

\author{
Wilson IB Onuigbo* \\ Department of Pathology, Medical Foundation \& Clinic, Nigeria
}

Submission: July 04, 2018; Published: July 26, 2018

*Correspondence Address: Wilson IB Onuigbo, Department of Pathology, Medical Foundation \& Clinic, 8 Nsukka Lane, Enugu 400001, Nigeria, Email: wilson.onuigbo@gmail.com

\section{Abstract}

It has been mooted that the establishment of a histopathology data pool facilitates epidemiological analysis. Therefore, such a pool, which was established in a developing community, was used to study biopsy cases of neurofibromatosis with special reference to those in which transformation of malignancy was suspected. Two such examples were found among some 163 random cases. They deserve documentation.

Keywords: Histopathology; Data pool; Analysis; Neurofibromatosis; Transformation; Malignancy; Igbos; Nigeria

\section{Introduction}

A Birmingham (UK) group hypothesized that the establishment of a histopathology data pool cannot but facilitate epidemiological analysis [1]. Therefore, since such a data pool was established at Enugu, the erstwhile capital city of the Eastern Region of Nigeria, can it be used to answer a genetic question? What of the Igbo ethic group [2]? This was answered personally as the pioneer pathologist who had encouraged local practitioners to send specimens provided the epidemiologic data were furnished in special Histology Request Forms.

\section{Case Reports}

EO, a 44-year-old woman, attended the Out-Patient Clinic run by Dr J.O. Ojukwu at the University of Nigeria Teaching Hospital, Enugu. The largest of her masses measured $5 \mathrm{~cm}$ by $5 \mathrm{~cm}$ and was situated on the right anterior chest wall. It was of 10 years duration. With the provisional diagnosis as "Neurofibromatosis with malignant transformation," excision biopsy was carried out. A $4.5 \mathrm{~cm}$ bosselated skin mass with underlying soft yellowish tumor tissue was received personally. On microscopy, the background was of benign tumor with neuroid elements. There were mitotically active, spindle cells manifesting hyperchromatism.

MJ, a 25-year-old man, attended the same Hospital under Dr D.C Nwafo with the complaints of swellings in the back of the chest and right thigh as well as all over the body. He was provisionally diagnosed as "Neurofibromatosis with malignant transformation." A $13 \mathrm{~cm}$ dome shaped sessile tumor was museum worthy on submission. There were other submitted irregular pieces including skin. On microscopy, some parts were benign with wavy spindle nuclei as well as mitotically active elements showing pleomorphism and hyperchromatism.

\section{Discussion}

Both manifestations were confirmed to have undergone malignant change. In this context, Internet searches yielded neurofibromas which became malignant in USA [3], and UK [4]. There were also UK \& Canada joint examples [5]. According to French authors [6], "The majority are indolent, but factors predictive of poor prognosis are yet to be identified." Hopefully, USA authors [7] recommended that "Multidisciplinary care at a high-volume sarcoma center is essential for optimal outcomes." "Further work," they added, "is needed to develop targeted combinational therapies for these tumors."

\section{References}

1. Macartney JC, Rollaston TP, Codling BW (1980) Use of a histopathology data pool for epidemiological analysis. J Clin Pathol, 33(4): 351-353.

2. Basden GT (1966) Niger Ibos. Cass, London, UK.

3. Korf BR (2000) Malignancy in neurofibromatosis type 1. Oncologist 5(6): 477-485.

4. Gareth D Evans R (2016) What is the malignancy risk in neurofibromatosis type 1? J Clin Oncol 34(17): 1967-1969.

5. Spurlock G, Knight SJL, Thomas N, Kiehl TR, Guha A, et al. (2010) Molecular evolution of a neurofibroma to malignant peripheral nerve sheath tumor (MPNST) in an NF1 patient: Correlation between histopathological, clinical and molecular findings. J Cancer Res Clin Oncol 136(12): 1869-1880.

6. Guillamo JS, Creange A, Kalifa C, Grill J, Rodriguez D, et al. (2003) Prognostic factors of CNS tumours in neurofibromatosis 1 (NF1): A retrospective study of 104 patients. Brain 126(1): 152-160. 


\section{Cancer Therapy \& Oncology International Journal}

7. Hirbe AC, Gutmann DH (2017) The management of neurofibromatosis type 1-associated malignant peripheral nerve sheath tumors: Challenges, progress, and future prospects. J Exp Opinion Orphan Drugs 5(8): 623-631.

This work is licensed under Creative Commons Attribution 4.0 License

DOI: 10.19080/CTOIJ.2018.11.555816
Your next submission with Juniper Publishers will reach you the below assets

- Quality Editorial service

- Swift Peer Review

- Reprints availability

- E-prints Service

- Manuscript Podcast for convenient understanding

- Global attainment for your research

- Manuscript accessibility in different formats ( Pdf, E-pub, Full Text, Audio)

- Unceasing customer service

Track the below URL for one-step submission https://juniperpublishers.com/online-submission.php 